\title{
THE HYDRO-TOURISM POTENTIAL OF THE LAND OF BEIUȘ
}

\author{
Laura Andreea LAZ $\breve{A R}^{1}$, Ioana Alexandra CIUPE ${ }^{1}$
}

\begin{abstract}
The hydro-tourism potential of the Land of Beiuș. The Land of Beiuss is undoubtedly the most scenic area in Bihor County. Its natural landscape is complemented by a series of cultural objectives that over time has made the area become a tourist destination for the adventurous, or on the contrary, for those who are looking for an oasis of peace. The region's hydrographic network represented by the river Crișul Negru, together with the mountainous scenery constitutes most of the tourism attraction. In this study, after a brief presentation of the geographic area, with an emphasis on the hydrographic aspects, we will focus on the research methodology utilized in the identification of the tourism potential generated by the rivers that cross the area. Then we will present the most important attractions of the region, and last but not least we will issue solutions to capitalize those resources and promote them on the tourism market. In the end, after we will get to know the area and it's tourism potential we will give forth some conclusions regarding the importance of discovering hydrographic resources and ways we can capitalize on them for the purpose of shaping a tourist destination.
\end{abstract}

Keywords: hydro-tourism, potential, rivers, resources, Land of Beiuș

\section{INTRODUCTION}

The concerns over this region, although being generous lately, leaves room for an original approach and thoroughgoing geographic study. Albeit the geographic basin of the river Crișul Negru and the afferent mountainous region were mentioned often in specialty literature, the complexity of the geographic factors imposes further research to shape the area that can become in time an important tourist attraction. In this regard, in the study that follows we will present the hydrographic resources that will be the pillar to developing a new form of tourism in the Land of Beiuss. Our purpose is to complete the tourism offer, to discover new ways to promote the area and to amplify the tourism in the county of Bihor.

The hydrographic basin of the river Crișul Negru presents a series of tourism characteristics, many of them already being exploited and some untapped or on course to being exploited. To better understand the tourism phenomenon in this area, the zones around the basin have been taken into consideration, because the Crișul Negru river streams act many times like a transit lane to the known tourism zones like the Apuseni Mountains or the Criș Mountains.

\footnotetext{
${ }^{1}$ Babeș-Bolyai University, Faculty of Geography, 400006 Cluj-Napoca, Romania, e-mail: lazarlaura90@yahoo.com, alexandra.ciupe@yahoo.com
} 
On the Land of Beiuș's territory, downstream Bătrâna Mountains, the hydrographic basin includes a series of valuable tourist attractions, generally speaking from the category of natural resources: gorges, caves, potholes, springs and, just beneath the Cucurbăta Peak from the Bihor Mountain, chain we come across the waterfall "The Holy Trinity" inside the valley of Poeini which gives tourists a spectacular representation.

\section{THE STUDY - AREA}

The Land of Beiuş is difficult to narrow out given that the region is shaped more by ethnographic aspects that need to be taken into account. However, over time, the researchers concluded that the country of Beiuş would be placed somewhere between the peaks, as a lowland area bordered by the Apuseni divisions (Fig.1): in the northern region Pădurea Craiului mountain group, Bihor and Vlădeasa to the east and the Codru Moma group to the south and south-east (Cocean, 2011).

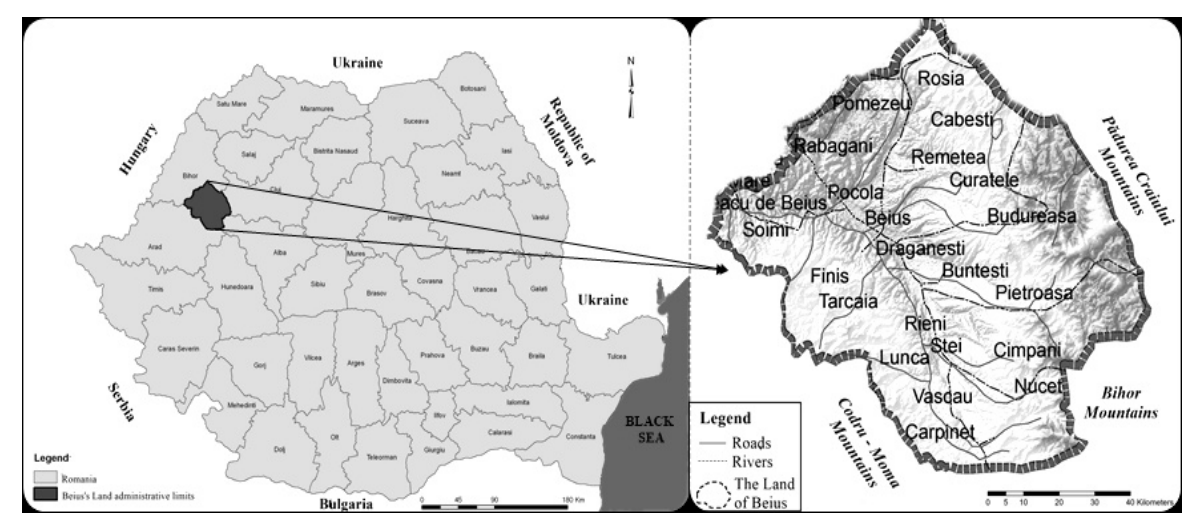

Fig. 1. Geographical location of the study area

Regarding the hydrographic network, in order to develop this study, the hydrographic basin was delimited with a total surface area of $4307 \mathrm{~km}^{2}$, from which $3165 \mathrm{~km}^{2}$ around Bihor county and $1142 \mathrm{~km}^{2}$ in Arad county (Tătar, 2009). As a result of its vast prevalence in the territory the largest tourism activity generator is in the upper part of the stream.

The hydrographic basin has a length of $100 \mathrm{~km}$ and a width of over $70 \mathrm{~km}$ and crosses the mountainous region from the depression of Beiuș. It receives its tributaries from the northern flank of the Bihor mountain range having a ramified fluvial network with asymmetry to the right.

Crișul Negru springs from an altitude of 1460 meters, from the northern slope of Peak Cucurbăta, upstream of Cărpinet village, having large decents with a rapid flow as a result of the river permeating the superior side of the corridor. The river exits the Land of Beiuş beyond Borz through a series of epigenetic paths dug in lime, then following a calm course from Tinca to the plains. 
It has just one tributary on the left side, Criștior, followed by the stream of Izbuc which springs from the karst plateau of Vașcău. Oproaia and Crișul Băița are the first tributaries from the right which, together with Sighiștel Valley offer numerous karst formations with over 150 caves. At Drăgănești, the river receives its most important tributary: Crișul Pietros formed from the Bulz and Galbenei Valley with an impressive sector of gorges. (Bîdiliță, F., 2009).

In Beiuș, Crișul Negru meets Roșia Valley, where tourists can find a series of karst features: gorges, caves, streams but also anthropic objectives like the famous watermill. After passing Roșia, the river leaves the Beiuș, depression through the lime "gates" between Petrani and Borz, where the narrow path is best highlighted (Fig.2).

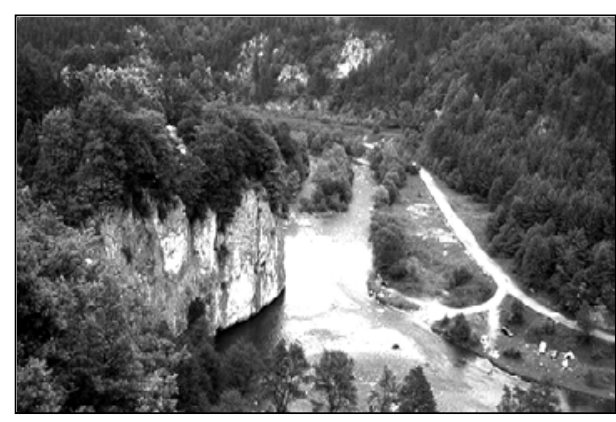

Fig. 2. Crișul Negru narrow path at Borz

\section{METHODOLOGY}

In this article, hydrologic, morphologic and economic data have been analyzed and processed whereas the study targets a possible tourism installation of the area through the discovery of touristic qualities of the water network in the Land of Beiuș. (Table 1).

Table 1. Hydroclimatic and morphological features of the Crișul Negru basin (Source: http://www.rowater.ro/dacrisuri/default.aspx)

\begin{tabular}{|c|c|c|c|c|c|c|c|}
\hline \multicolumn{2}{|c|}{ Climate data } & \multicolumn{3}{|c|}{ Morphological data } & \multicolumn{3}{|c|}{ Hydrographical network } \\
\hline $\begin{array}{c}\text { Average } \\
\text { temperature }\end{array}$ & $\begin{array}{c}\text { Average } \\
\text { precipitations }\end{array}$ & $\begin{array}{l}\text { High } \\
\text { altitude }\end{array}$ & $\begin{array}{c}\text { Minimum } \\
\text { altitude }\end{array}$ & $\begin{array}{c}\text { Average } \\
\text { slope }\end{array}$ & $\begin{array}{l}\text { Surface } \\
\text { and } \\
\text { length }\end{array}$ & Density & $\begin{array}{c}\text { Average } \\
\text { flow }\end{array}$ \\
\hline $\begin{array}{l}40^{\circ} \mathrm{C}-\text { in the } \\
\text { mountain } \\
\text { area } \\
>100^{\circ} \mathrm{C} \text { in } \\
\text { the plains }\end{array}$ & $\begin{array}{l}1600 \mathrm{~mm}-\text { in } \\
\text { the mountain } \\
\text { area } \\
500-600 \mathrm{~mm} \\
\text { - in the plains }\end{array}$ & $\begin{array}{l}1849- \\
\text { Bihor } \\
\text { Peak }\end{array}$ & $\begin{array}{l}89 \mathrm{~m}- \\
\text { leaving the } \\
\text { country }\end{array}$ & $8 \%$ & $\begin{array}{l}4307 \\
\mathrm{~km}^{2} \\
164 \mathrm{~km}\end{array}$ & $\begin{array}{l}0.39 \\
\mathrm{~km} / \mathrm{km}^{2}\end{array}$ & $31,4 \mathrm{~m}^{3} / \mathrm{s}$ \\
\hline
\end{tabular}

The map was made with the help of ArcGis10 program. The data concerning the hydrological characteristics of the river Crișul Negru have been processed after the Rivers' Water Basin Administration, Oradea and other specialized websites like www.rowater.ro, and the main tourism atraction were described by consulting the bibliography.

\section{RESULTS AND DISCUSSION}

The tourism in the Land of Beiuș at this moment is counting on the promotion of cultural objectives and less on the nature aspect. In the Land of Beiuss 
we can find a lot of natural objective of hydrologic origin. We mention here the course of the river Crișul Negru that passes through the whole depression, but also the other elements that can become a tourist attraction: valleys, gorges, gullets, waterfalls or streams.(Fig. 3)

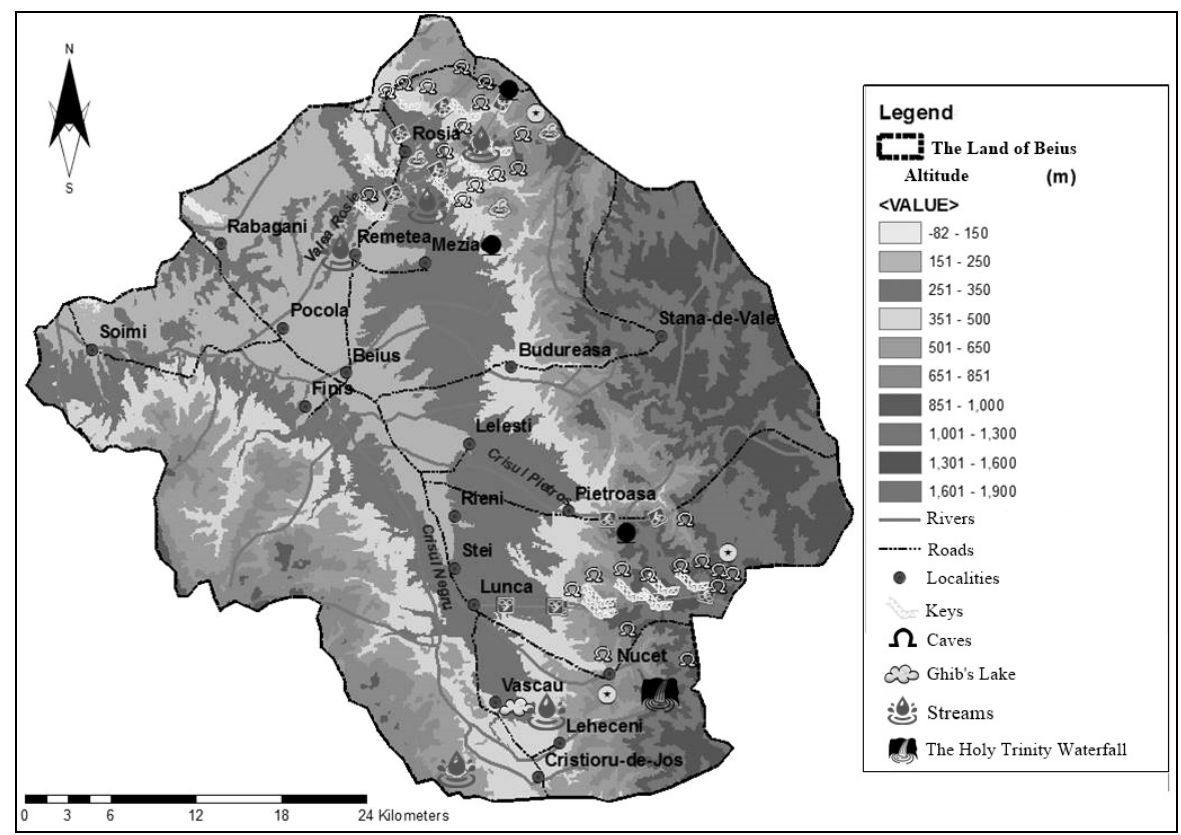

Fig. 3. Natural tourism resources in the Land of Beiuș

The top attractions are without a doubt the waterfalls and, even if many don't know about their existence, in the Land of Beius, we meet 3 of these objectives known as "The Holy Trinity". It is formed from 3 separate waterfalls which stream right beneath Cucurbăta Peak, near the village of Poiana. The three waterfalls: Cârligoi 40 meters, Hotăran 80 meters and Fântânele 65 meters, through friction a ionization in the air that offer its visitors a unique sensation. (Berindei, I., Zara, N., 1997).

The largest and most beautiful waterfall is Hotăran (Fig.4) which pours from the forrest in on three steps making a spectacular view. When seen from its base only the first step is visible measuring 30 meters. To get to the second step you can climb a steep path on the right side of the first waterfall.

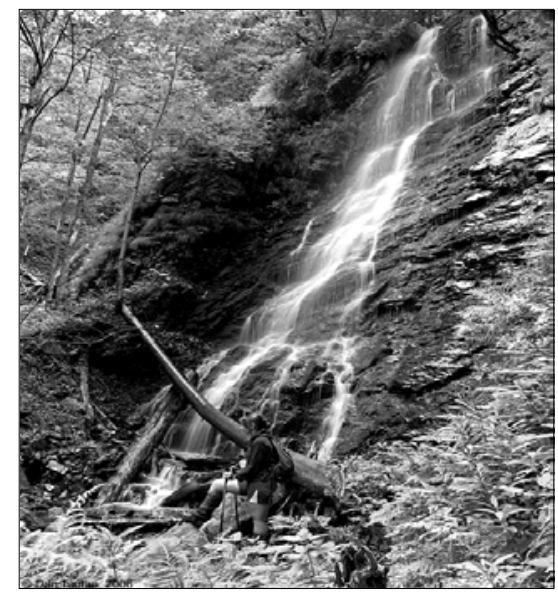

Fig. 4. Hotăran Waterfall 
A lesser known place but unique in the country: very steep valleys through numerous steps, in a symphony of waters, that's how it would be best described.

Another attraction would be the stream Boiu, its waters never freeze. The stream is situated near the center of Vaşcău, having a very strong flow and a constant water temperature all year. Its origins come from the Pampar river which falls in the Câmpeneasca cave through a spectacular waterfall of about 35 meters in height and, after it traverses

about 2 kilometers underground it emerges near Vașcău under the form of a stream. The waterfall inside the cave is considered one of the biggest underground waterfalls in Romania and one of the most beautifull in Europe.

Known as the "fountain of renewal" the stream from Călugari attracts thousands of believers yearly, who come for prayer and for the water that is considered to have miraculous powers. Situated at the easter foot of the mountain chain Codru-Moma, the intermittent stream has a peculiar way to function: the stream has a bathtub form with a diameter of $60 \mathrm{~cm}$ and a depth of 1 meter which extends with a natural canal. Every 10-20 minutes, the stone vat fills with water and then pours out. To get filled it needs approximately one hour; through this unequal rhythm named the double rhythm, the stream is considered as being a unique hydrologic phenomenon. Also, the rhythmicity is influenced by seasons.

At the Vașcău plateau, the permanent waters are very representative, almost all of them disappearing in the slopes. There are numerous pans in the valleys, small lakes the most notable being: The marble anthropic lake, The lake of Barna, Iezer, Ursului, Lupui, Dîmbu, Șoimului, Ponor from Câmp-Moți, Țapului and last but not least Ghib’s lake.

Ghib's lake is a valley lake, situated at only $3 \mathrm{~km}$ distance from the village Cărpinet, near the forrest road which links Izbuc to Ponor valley. Ghib's lake represents a rarity in the lime landscape in our country, very picturesque through its bright red clay, which coats the valley, in contrast with the white of the lime that lies beneath and with the intense green of the marsh vegetation.

Ghib's lake was formed due to its impermeable clay slopes that calcified and has a length of approximately 60 meters and a width of 20 meters. The lake is constantly being fueled by tributaries and streams that form after heavy rainfall from the valleys in the region, and from underground streams. (Filimon, Luminiţa, 2012).

Last but not least, a valuable tourism attraction is the river Crișul Negru and its tributaries. Used for swimming, fishing and lately extreme sports this river offers tourists diverse ways to spend their time.

Crișul Pietros started not long ago to be an important tourist attraction for the adrenaline lovers, rafting developed with the help of small entrepreneurs which organize guided hikes in favorable weather conditions. The accessible upstream end which is situated between the valleys Boga and Galbena at an altitude of 550 meters, and the end from downstream at Pietroasa with an altitude of 400 meters. The total distance you can cover on water: 8 kilometers. The estimative time to cover it is about 2-2.5 hours. The time of year when the waters are navigable is 
between april-may and in rainy periods. It's approachable with kayaks and rafts (only in deep waters). In spring time there can be an accumulation of logs on the waters shores. (http://rafting-kayaking.ro/a01_rauri.html)

To all this add the valleys of impressive streams that through their geological nature have made impressive lime attractions. We're talking about Sighiștel valley considered "speologist paradise", the valley Roșia with waterfalls from the Lazuri keys, the valley of Cuți, Tăracăiței etc.

\section{CONCLUSIONS}

The approach to this study concerning the identification and evaluation of the hydro-touristic potential from the land of Beiuş has followed all the specific logical steps: the identification of geo-physic limitations that define the zone (both spatially and regionally), the general characteristics of water resources, the identification of resources that can become a pillar for tourism in the area and the discovery of possible ways to exploit these objectives.

We can observe, in hindsight of this presentation, that the Land of Beius, besides having cultural beauty has a series of natural attractions, from which the hydrographic attractions are a great deal. The promotion of these on the tourism market should become a priority for the service providers to shape a "complete" tourism environment which could offer the tourist a vast category of objectives and possibilities for recreation and spending their free time. The promenades along the impressive valleys, the discovery of mountain passes, waterfalls unknown by many, fishing at the river edge, or visiting the lakes and streams are just a few of the activities that can become a touristic offer. Currently none of these attractions are included in any approved touristic circuit, and only the tourist can discover them alone, if he has any luck.

\section{REFERENCES}

1. Berindei, I., Zara, N., (1997), Potențialul turistic al județului Bihor, în Lucrări Ştiințifice, Seria A, Institutul Oradea

2. Bîdiliță, F., (2009), Bazinul Crișului Negru - Studiu de geomorfologie cu privire special asupra reliefului fluvial şi fluvio-denudațional, Teză de doctorat (http://www.uoradea.ro/attachment/791672704232e82e41d0a31a6bc16159/798db 7459fc7f775f9b3e532cbe711da/bidilita_florina.pdf)

3. Cocean, P., (2011), ,Ţările”- regiuni geografice şi spaţii mentale, Editura Presa Universitară Clujeană, Cluj-Napoca.

4. Filimon, Luminiţa, (2012), Ţara Beiuşului - Studiu de geografie regională, Editura Presa Universitară Clujeană, Cluj-Napoca.

5. Inskeep, E., (1994), National and Regional Tourism Planning, Routledge

6. Tătar, Corina - Florina, (2009), Posibilități de valorificare a resurselor turistice din Bazinul hidrografic Crișul Negru, Editura Universității din Oradea, Oradea

7. http://www.rowater.ro/dacrisuri/default.aspx, accesed on December 20, 2016

8. http://rafting-kayaking.ro/a01_rauri.html, accesed on January, 6, 2017 


\section{REFERENCES}

1. Berindei, I., Zara, N., (1997), Potențialul turistic al județului Bihor, în Lucrări Științifice, Seria A, Institutul Oradea

2. Bîdiliță, F., (2009), Bazinul Crișului Negru - Studiu de geomorfologie cu privire special asupra reliefului fluvial și fluvio-denudațional, Teză de doctorat

(http://www.uoradea.ro/attachment/791672704232e82e41d0a31a6bc1615 9/798db7459fc7f775f9b3e532cbe711da/bidilita_florina.pdf)

3. Cocean, P., (2011), „Ţările”- regiuni geografice şi spaţii mentale, Editura Presa Universitară Clujeană, Cluj-Napoca.

4. Filimon, Luminiţa, (2012), Ţara Beiuşului - Studiu de geografie regională, Editura Presa Universitară Clujeană, Cluj-Napoca.

5. Inskeep, E., (1994), National and Regional Tourism Planning, Routledge

6. Tătar, Corina - Florina, (2009), Posibilități de valorificare a resurselor turistice din Bazinul hidrografic Crișul Negru, Editura Universității din Oradea, Oradea

7. http://www.rowater.ro/dacrisuri/default.aspx, accesed on December 20, 2016

8. http://rafting-kayaking.ro/a01_rauri.html, accesed on January, 6, 2017 